\title{
On Thermal Acceleration of Medical Device Polymer Aging
}

\author{
Janting, Jakob; Theander, Julie G.; Egesborg, Henrik
}

Published in:

IEEE Transactions on Device and Materials Reliability

Link to article, DOI:

10.1109/TDMR.2019.2907080

Publication date:

2019

Document Version

Peer reviewed version

Link back to DTU Orbit

Citation (APA):

Janting, J., Theander, J. G., \& Egesborg, H. (2019). On Thermal Acceleration of Medical Device Polymer Aging. IEEE Transactions on Device and Materials Reliability, 19(2), 313-321.

https://doi.org/10.1109/TDMR.2019.2907080

\section{General rights}

Copyright and moral rights for the publications made accessible in the public portal are retained by the authors and/or other copyright owners and it is a condition of accessing publications that users recognise and abide by the legal requirements associated with these rights.

- Users may download and print one copy of any publication from the public portal for the purpose of private study or research.

- You may not further distribute the material or use it for any profit-making activity or commercial gain

- You may freely distribute the URL identifying the publication in the public portal

If you believe that this document breaches copyright please contact us providing details, and we will remove access to the work immediately and investigate your claim 


\title{
On Thermal Acceleration of Medical Device Polymer Aging
}

\author{
Jakob Janting, Member, OSA, Julie G. Theander and Henrik Egesborg
}

\begin{abstract}
An empirical rule, the $10^{\circ} \mathrm{C}$ rule, states that chemical reaction rates are doubled for every $10^{\circ} \mathrm{C}$ temperature increase. This is often used in thermally accelerated medical device polymer aging studies. Here, theoretical evidence and limitations for the rule are analyzed. Thus, a new more accurate rule based on averaging Arrhenius chemical reaction rate ratios over typical activation energies $0.1 \mathrm{eV}-0.9 \mathrm{eV}$ in the normal medical device accelerated test temperature interval $25^{\circ} \mathrm{C}-70^{\circ} \mathrm{C}$ is proposed. Comparison with the $10^{\circ} \mathrm{C}$ rule shows that the $10{ }^{\circ} \mathrm{C}$ rule provides similar estimates, but only at the reference temperature $25^{\circ} \mathrm{C}$. Fitting the reaction rate ratio based on the Arrhenius equation using the reference temperature $25^{\circ} \mathrm{C}$ to the $10{ }^{\circ} \mathrm{C}$ rule data reveals that best agreement is achieved with a thermal aging activation energy of $0.67 \mathrm{eV}$.
\end{abstract}

Index Terms-Medical devices, polymer degradation, thermal acceleration, $10{ }^{\circ} \mathrm{C}$ rule analysis, activation energies.

\section{INTRODUCTION}

$\mathbf{T}$ ODAY polymer materials have spread to almost any product. They have many roles in making up whole products by themselves and by serving as passive/active components of products also containing other materials. Often they have to be very durable towards exposure to harsh environments like in microelectronics, microsensors, implants etc. This demand is getting very critical as products get more and more miniaturized and especially when the polymer has a protection or barrier role towards aggressive surroundings [1]. Accordingly, for economic and safety reasons, there is a need for more accurate product life time estimates.

The rule that the polymer thermal aging rate $k$ is doubled for every $\Delta T=10^{\circ} \mathrm{C}$ temperature increase from a reference temperature $T_{1}$, the $10{ }^{\circ} \mathrm{C}$ rule eq. (1), is widely used in the literature and on the internet.

$$
k\left(T_{1}+\Delta T\right) \approx 2^{\Delta T / 10^{\circ} \mathrm{C}} \cdot k\left(T_{1}\right)
$$

For instance, in medical device $R \& D$ it is used as a quick guideline for polymer screening. However, it should be remembered that the equation is purely phenomenological, i.e. it has some predictive value but has no theoretical or scientific foundation. Thus, we do not concur with the often seen views that [2]-[5]:

Manuscript received...

J. Janting is with DTU Fotonik, Department of Photonics Engineering, Technical University of Denmark, 2800 Kongens Lyngby, Denmark, e-mail: jajant@fotonik.dtu.dk.

J. G. Theander is with ConvaTec, Aaholmvej 1, Osted, 4320 Lejre, Denmark, email: Julie.theander@convatec.com.

H. Egesborg is with MedDevCon, Medical Device Consulting, Ewaldsbakken 11, 2900 Hellerup, Denmark, e-mail: meddevcon@email.dk.
1) The eq. (1) version is based on the Arrhenius equation.

2) The rate always doubles for every $10^{\circ} \mathrm{C}$ temperature increase.

3) For a given reaction/aging the rule is valid at all reference temperatures $T_{1}$.

We think, that also just as a guideline, the rule may be too broadly relied on and that this may result in inaccurate thermal aging rate estimates. Therefore and generally, we believe that there is a need for our critical review and analysis of the simple empirical rule. It is especially critical that the rule has entered medical device standards [3], [6] without a more critical analysis on the accuracy, as also pointed out by Lambert et al. [5], who also made an analysis on the temperature independence of the rule. Here, Van't Hoff is correctly attributed to the rule. However, his detailed observations are not quoted, which also here leads to the first two views mentioned above.

Below, the background and limitations for the $10^{\circ} \mathrm{C}$ rule are analyzed. Furthermore, a new and better guideline rule based on the Arrhenius equation and thus exhibiting reference temperature $T_{1}$ dependence is proposed. The rule analysis is based on a comparison with Arrhenius equation reaction rate ratio behavior as a standard and here the term "aging" includes any process, also physical, which can be thermally accelerated and which obeys the Arrhenius equation. It is also important to note that the analysis is limited to normal temperatures defined to be $25^{\circ} \mathrm{C}-70{ }^{\circ} \mathrm{C}$ because probably the rule has it origin from most observations here, but also because this interval is often used in medical device testing. The analysis is limited to single processes and temperature intervals where the polymer exhibits no transitions in phase or aging mechanism i.e. activation energy. We use $\mathrm{eV}$ as the activation energy unit in all calculations. In the polymer aging litterature the SI unit $\mathrm{kJ} / \mathrm{mol}$ is also frequently used. For those feeling more comfortable with that unit the conversion is $1 \mathrm{eV}=96 \mathrm{~kJ} / \mathrm{mol}$.

\section{EMPIRICAL AND THEORETICAL FOUNDATION OF THE RULE}

\section{A. The origin of the 10-degree rule}

In the literature the 10-degree rule is also called the $Q_{10}$ rule, the RGT-rule (ReaktionsGeschwindigkeit-Temperaturrule) [7] and the Van't Hoff's rule [8] and is usually written like in eq. (2).

$$
Q_{10}=\left(\frac{k\left(T_{2}\right)}{k\left(T_{1}\right)}\right)^{\frac{10^{\circ} \mathrm{C}}{\Delta T}} \approx 2 \text { for } \Delta T=T_{2}-T_{1}=10^{\circ} \mathrm{C}
$$


The latter name is perhaps the most adequate because it was Jacobus Hendricus Van't Hoff, the first Nobel Prize winner in chemistry, who discovered the rule in 1896 [9]-[12]. In his own words [9]:

"The great majority of cases which have as yet been investigated in this direction have been studied in the interval of temperature lying between $0{ }^{\circ} \mathrm{C}$ and $184^{\circ} \mathrm{C}$ and it is very striking that the ratio of the velocity constants for two temperatures differing by 10 degrees has a value between 2 and 3 approximately. In other words, a rise of temperature of $10^{\circ} \mathrm{C}$ doubles or trebles the velocity of a reaction."

Van't Hoff then refers to a table in the text where actually, to be more accurate, the ratio for different reactions varies between 1.89 and 3.63. Here, the main thing to note is that Van't Hoff is not saying that the ratio is always 2, but that it varies between approximately 2 and 3 . Then more correctly the $Q_{10}$ rule eq. (2) should be:

$$
\frac{k\left(T_{2}\right)}{k\left(T_{1}\right)}=Q_{10}^{\frac{\Delta T}{10^{\circ} \mathrm{C}}} \in\left[2^{\frac{\Delta T}{10^{\circ} \mathrm{C}}}, 3^{\frac{\Delta T}{10^{\circ} \mathrm{C}}}\right]
$$

1) Semi-empirical analysis of the rule's temperature dependence: Van't Hoff proved from thermodynamics that the temperature dependence of the chemical reaction rate must be described by his equation (the Van't Hoff equation) from 1884 [13] where $\mathrm{A}^{\prime}$ and $\mathrm{B}$ are constants:

$$
\frac{\partial \ln k}{\partial T}=\frac{\mathrm{A}^{\prime}}{T^{2}}+\mathrm{B}
$$

Van't Hoff notes that the observed $10^{\circ} \mathrm{C}$ rule behavior is well described by Berthelot's equation from 1862, which correspond to putting $\mathrm{A}^{\prime}=0$ in Van't Hoff's equation and integrate:

$$
k=\mathrm{Ae}^{\mathrm{B} T}
$$

So, according to Berthelot, taking the ratio of the rate constants at two different absolute temperatures $T_{2}>T_{1}, \Delta T=T_{2}-T_{1}$ we get:

$$
\frac{k\left(T_{2}\right)}{k\left(T_{1}\right)}=\mathrm{e}^{\mathrm{B} \Delta T}
$$

which would mean that reaction rate ratios, in contradiction with experiments, exhibit no reference temperature $T_{1}$ dependence. However, eq. (5)

"reproduces the chief characteristic of the relation between velocity of a reaction and temperature, which is that if the temperatures form an arithmetical series, the rates of change at these temperatures will form a geometrical series" [9].

This is also explained by Cohen [14] and Cossins [15]. Due to this behavior, Bertheloth's equation (5) was not only believed for a long time as stated by Laidler [10] but is actually still to a large extent believed, which can be seen from the similarity of eq. (1) and eq. (6).

Svante Arrhenius found 1889 experimentally [16], that $B=$ 0 and contributed theoretically to the understanding of reaction rates with basic ideas about the transition state concept of the reaction activation energy $E_{a}$ in $A^{\prime}=\frac{E_{A}}{\mathrm{k}_{\mathrm{B}}}$ where $\mathrm{k}_{\mathrm{B}}$ is
Boltzman's constant $\left(8.617 \cdot 10^{-5} \mathrm{eV} / \mathrm{K}\right)$, leading to the the Van't Hoff equation in the form:

$$
\frac{\partial \ln k}{\partial T}=\frac{E_{A}}{\mathrm{k}_{\mathrm{B}} T^{2}}
$$

and after integration the famous Arrhenius equation:

$$
k=\mathrm{Ae}^{-\frac{E_{A}}{\mathrm{k}_{\mathrm{B}} T}}
$$

Van't Hoff was aware that the activation energy is slightly temperature dependent but Arrhenius assumed no such temperature dependence. Many other mathematical expressions were suggested to account for the temperature dependence of reaction rates around that time, but without including any theory. Using eq. (8), the ratio $\rho$ of rate constants at two different absolute temperatures $T_{2}>T_{1}, \Delta T=T_{2}-T_{1}$ is:

$$
\rho=\frac{k\left(T_{2}\right)}{k\left(T_{1}\right)}=\mathrm{e}^{\frac{E_{A}}{\mathrm{k}_{\mathrm{B}}} \frac{\Delta T}{T_{1}\left(T_{1}+\Delta T\right)}}
$$

which is dependent on the reference temperature $T_{1}$. The graph in Fig. 1 depicts this ratio as a function of $T_{1}=T_{2}-\Delta T$ and $E_{A}$ where $\Delta T=10^{\circ} \mathrm{C}$. Clearly, $\rho$ decreases with increasing $T_{1}$ and increases with increasing $E_{a}$. Van't Hoff's observation was, that for reactions corresponding to $E_{A}$ 's in Fig. 1, the average of $\rho$ values for $\Delta T=10^{\circ} \mathrm{C}$ steps over different temperature intervals is approximately 2 to 3 . Looking closer at Fig. 1, it can be seen that the range of $\rho$ 's for the same increase of $T_{1}$, increases with $E_{A}$.

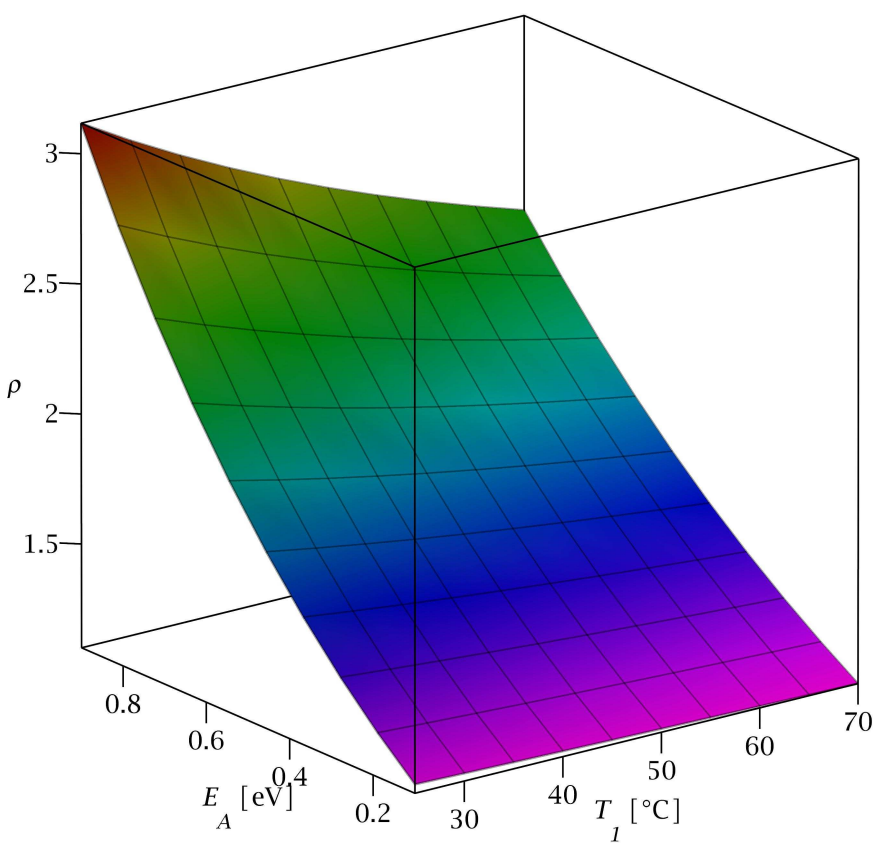

Fig. 1. Temperature and activation energy dependence of Van't Hoff's rule eq. (9), where $T_{1}=T_{2}-\Delta T$ and $\Delta T=10^{\circ} \mathrm{C}$.

Already in 1912, 16 years after Van't Hoff's discovery of the rule, the misconceptions were widespread, mainly due to physiologists

"who like to make use of the temperature coefficient in order to decide from its magnitude whether a given process is chemical or physical" [14]. 
Thus, low $Q_{10}$ values in the interval [1,2] indicate physical processes like diffusion, osmosis etc. rather than e.g. chemical metabolism processes $\left(Q_{10} \in[2,3]\right)$. However, these intervals depend on the reference temperature $T_{1}$. Note here, that to the left in Fig. 1, the surface cut at $T_{1}=25^{\circ} \mathrm{C}$ shows the course of $\rho_{25^{\circ} \mathrm{C}}$ lying approximately in the interval $[1,3]$. Cohen Stuart [14] also gives a functional behavior analysis demonstrating the temperature dependence of the rule. Besides our work, the rule analyses by Hukins et al. [2], Lambert et al. [5] and Cohen Stuart [14] are the only others known to us.

\section{AVERAge RAte RAtios}

Since the $10^{\circ} \mathrm{C}$ rule, eq. (1), is an empirical rule, it is based on average reaction/process observations and more theoretically an average of $\rho\left(T_{1}, \Delta T, E_{a}\right)$ presuming the Arrhenius reaction rate equation eq. (8) applies. Note, that Van't Hoff's finding, that for different reactions $\left(E_{A}\right.$ 's) $\rho \in[2,3]$ for $\Delta T=10^{\circ} \mathrm{C}$, was also based on $\Delta T=10^{\circ} \mathrm{C}$ increment averages over different temperature intervals. However, he did not make averages over different $E_{A}$ 's as we have done. But why is the quotient in eq. (2), which has been the prevailing version of the rule for more than 100 years, then not any other number than 2 in this interval? It is most likely because his observation was based on a limited number of reactions/processes compared to a much broader later use of the rule [14]. Note already here, that if we simply include low $E_{A}$ reactions and physical processes, then $\rho \in[1,3]$ for which the median is 2 .

\section{A. Range of aging activation energies}

Today $E_{A}$ 's for many more reactions and physical processes are known. Here, this will be used to study the validity of the rule, eq. (2), by analyzing averages of $\rho$. Polymers degrade in many different ways under normal service exposure to temperature, humidity, radiation and chemicals [17]-[21]. This may explain why it has not been possible to find any general statements about typical polymer aging activation energies. However, below it is demonstrated, that from theory and several chemical and physical observations, there are good indications that the interval $0.1 \mathrm{eV}-0.9 \mathrm{eV}$ is valid for aging of polymers and other materials as well in the typical temperature interval $25^{\circ} \mathrm{C}-70^{\circ} \mathrm{C}$.

1) Chemical reactions: The chemical reactions considered here involve a transition or activated state which implies activation energies lower than the energy of the bonds broken in the reactions. This is because in one process, i.e. the transition state, the energy required for the breaking of bonds is partly compensated for by the energy gained by new bonds being formed [22]. Average chemical bond energies can be found in many textbooks [23], handbooks [24] and are usually in the range $1.5 \mathrm{eV}-9 \mathrm{eV}$. A reliable source of kinetic data for numerous specific reactions including activation energies is the National Institute of Standards and Technology (NIST) [25].

The activation energy has been found theoretically to be the average total energy, translational plus internal, of all reacting pairs of reactants minus the average total energy of all pairs of reactants [26], [27]. Catalysts for chemical reactions work by lowering $E_{A}$, i.e. this energy difference. The short distance interactions responsible for the $E_{A}$ lowering in condensed matter are not present to the same extent in gasses where activation energies are higher, usually $0.8 \mathrm{eV}-4 \mathrm{eV}$ [12]. Note, that the average molecular kinetic/thermal energy at room temperature $T=300 K$ is only $\frac{3}{2} \mathrm{k}_{\mathrm{B}} T=0.04 \mathrm{eV}$. The information below concerns solid or liquid state changes only. Thus, $E_{A}$ 's range from a few hundredths $\mathrm{eV}$ to chemical bond energies [28], [29] at around $1.5 \mathrm{eV}$.

a) Activation energies from Van't Hoff's rule: By combining Van't Hoff's observations and eq. (9) we get for $T_{1}=T_{2}-\Delta T=25^{\circ} \mathrm{C}$ and $\Delta T=10^{\circ} \mathrm{C}$ :

$$
\begin{aligned}
E_{A} & \in\left[\ln 2 \cdot \mathrm{k}_{\mathrm{B}} \frac{T_{1}\left(T_{1}+\Delta T\right)}{\Delta T}, \ln 3 \cdot \mathrm{k}_{\mathrm{B}} \frac{T_{1}\left(T_{1}+\Delta T\right)}{\Delta T}\right] \\
& \in[0.55 \mathrm{eV}, 0.87 \mathrm{eV}]
\end{aligned}
$$

b) Polymers: Many $E_{A}$ 's for polymer degradation under different test conditions have been published. Most values seem to come from microelectronic component testing (see below) where electric functionality failure is used to indirectly determine polymer degradation $E_{A}$ 's. Here, a short overview is given on results from some tests made directly on the polymers.

According to Mott et al. [30] the aging $E_{A}$ for natural rubber in air and seawater is $0.93 \mathrm{eV}$ and $0.65 \mathrm{eV}$ respectively. Degradation was detected by observing changes in elongation to failure. The difference was linked to the differences in oxygen concentration in the two environments. Degradation as a function of temperature for PU, EPDM and butyl rubber elastomers has been tested by monitoring oxygen consumption [31]. The range of $E_{A}$ for these elastomers was found to be $0.62 \mathrm{eV}$ to $0.81 \mathrm{eV}$ in the temperature range $25^{\circ} \mathrm{C}$ to $80^{\circ} \mathrm{C}$. In this reference the authors have also collected similar independent data on degradation of PP. This overview shows that activation $E_{A}$ 's for thermo-oxidative degradation of PP are in the range $0.37 \mathrm{eV}$ to $0.51 \mathrm{eV}$ for test temperatures below $80^{\circ} \mathrm{C}$. Activation energies between $0.04 \mathrm{eV}$ and $0.99 \mathrm{eV}$ for a number of different PA66 degradation mechanisms are mentioned by Gonçalves et al. [32]. The degradation of PC films in water at temperatures between $70^{\circ} \mathrm{C}$ and $90^{\circ} \mathrm{C}$ has been studied by observing $50 \%$ reduction in strain to break [33]. The corresponding activation energy was found to be $0.71 \mathrm{eV}$. Pickett et al. [34] found that yellowing or gloss loss due to weathering have activation energies $0 \mathrm{eV}$ to $0.31 \mathrm{eV}$ for many aromatic thermoplastic polymers.

Polymerization/depolymerization activation energies may give an indication of involved activation energies in polymer degradation with absence of external molecules. In free radical polymerization $E_{A}=\frac{1}{2} E_{D}+\left(E_{P}-\frac{1}{2} E_{T}\right)$ where $E_{D}, E_{P}$, $E_{T}$ are the activation energies for initiation (photoinitiator decomposition), propagation and termination respectively. Photopolymerization reactions which do not involve a temperature dependent initiation (no $E_{D} \in[1.30 \mathrm{eV}, 1.76 \mathrm{eV}]$ term) have typical $E_{A}$ 's in the range $0.22 \mathrm{eV}$ to $0.26 \mathrm{eV}$ [35], [36]. Cationic polymerization activation energies $E_{A}=E_{I}+E_{P}-$ $E_{T}$ where $E_{I}, E_{P}, E_{T}$ are the initiation, propagation and 
termination components, are typically in the range $-0.42 \mathrm{eV}$ to $0.62 \mathrm{eV}$ [36]. Depolymerization activation energies are normally $0.43 \mathrm{eV}$ to $1.13 \mathrm{eV}$ [35].

c) Microelectronics: According to a list made by Lall [37], degradation $E_{A}$ 's comprising all chemical and physical mechanisms in microelectronics are between $-0.06 \mathrm{eV}$ (hot carrier) and $2.1 \mathrm{eV}$ (time dependent dielectric breakdown). However, most of the mentioned values seem to be between $0.3 \mathrm{eV}$ and $1 \mathrm{eV}$. McPherson mentions the rule of thumb $E_{A} \approx$ $1 \mathrm{eV}$ [38]. The author of this book has a background from the electronics industry and thus the book is clearly biased in that direction. Activation energies for polymer degradation are not mentioned by Lall [37] and McPherson [38], but since many different materials are used in microelectronics, also polymers, $E_{A} \approx 1 \mathrm{eV}$ is probably also quite valid for polymers used in this industry, which are typically epoxies. This is well supported by Hallberg et al. [39] who found an average value for long lived epoxy molded chips to be $0.9 \mathrm{eV}$. Note, that most microelectronics polymer degradation activation energies are found indirectly by observing the time to device or component electrical failure. This means that the observed values may be composite apparent activation energies [40]. Similar $E_{A}$ 's can be found for e.g. polymers like EVA typically used in photovoltaic modules. A literature survey has been made, which indicate that for these polymers $E_{A} \in[0.31 \mathrm{eV}, 0.62 \mathrm{eV}]$ for photochemical degradation processes and $E_{A} \in[0.62 \mathrm{eV}, 0.93 \mathrm{eV}]$ for thermal degradation processes [41].

Today, in accordance with microelectronics standards, the activation energy is estimated to be $0.7 \mathrm{eV}$ if it is unknown. Interestingly, this estimate has increased from approx. $0.4 \mathrm{eV}$ over the years, which is probably due to higher materials purity, better product designs etc. [42].

d) Biology and environment: A thorough statistical study on the variation of activation energies for important metabolic reactions across different species is provided Dell et al. [43]. From the large amount of data they found that $E_{A} \in$ $[0.2 \mathrm{eV}, 1.2 \mathrm{eV}]$ with a mean value of $0.65 \mathrm{eV}$.

Transformation rates of pesticides in soil is dealt with by the European Food Safety Authority (EFSA) [44]. The median $E_{A}$ for all such compounds has been found to be $0.68 \mathrm{eV}$. Further, it is found that that there is $90 \%$ probability that the median $E_{A}$ is in the interval $[0.47 \mathrm{eV}, 0.97 \mathrm{eV}]$.

e) Geology: According to Wolery [45] typical chemical reaction activation energies are $0.42 \mathrm{eV}-0.83 \mathrm{eV}$. However, it is not clear whether this is a statement only valid for certain geochemical reactions.

2) Physical chemistry:

a) Polymer cohesion: The properties of polymers are often strongly affected by the presence of solvents. As a solvent penetrates a thermoplastic amorphous polymer it may degrade by swelling or dissolution. The polymer dissolution activation energy $E_{A}$ is determined by [46]:

$$
E_{A}=E_{C O H}=\delta^{2} V_{M}=\Delta H_{V A P}-\mathrm{k}_{\mathrm{B}} T
$$

where $E_{C O H}, \delta, V_{M}, \Delta H_{V A P}$ are the polymer cohesion energy, total solubility parameter, molar volume and enthalpy of vaporization respectively. Polymer dissolution activation energies for a range of common amorphous and semi-crystalline polymers are given in Table I.

TABLE I

Polymer disSOLUtion aCtivation ENERgIES $E_{A}$ CALCULATEd by USING THE Hansen SOlubility Parameters In PRACTICE (HSPiP) SOFTWARE, $5^{\text {th }}$ EDITION. THE POLYMER SMILES (SIMPLIFIED

MOLECULAR-INPUT LINE-ENTRY SYSTEM) WERE USED AS SOFTWARE INPUT TO FIND $\delta$ AND $V_{M}$ BY THE GROUP CONTRIBUTION METHOD. NOTE, THAT POLYMERS FROM PE DOWN ARE SEMI-CRYSTALLINE, WHICH MEANS THAT THEY WILL HAVE TO BE HEATED IN THE SOLVENT TO GET MORE AMORPHOUS BEFORE THEY CAN DISSOLVE.

\begin{tabular}{ccc}
\hline \hline Polymer & SMILES & $\boldsymbol{E}_{\boldsymbol{A}}(\mathbf{e V})$ \\
\hline PVC & $\mathrm{CC}(\mathrm{Cl})$ & 0.19 \\
PMMA & $\mathrm{CC}(\mathrm{C})(\mathrm{C}(\mathrm{OC})=\mathrm{O})$ & 0.32 \\
PS & $\mathrm{CC}(\mathrm{C}(\mathrm{C}=\mathrm{C} 1)=\mathrm{CC}=\mathrm{C} 1)$ & 0.37 \\
COC & $\mathrm{C}=\mathrm{CC} \backslash 1=\mathrm{C} \backslash \mathrm{C} 2 \mathrm{CC} / \mathrm{CC} 2$ & 0.41 \\
ABS & $\mathrm{C}=\mathrm{CC}=\mathrm{CC}=\mathrm{CC} \# \mathrm{NC}=\mathrm{CC} 1=\mathrm{CXC}=\mathrm{CC}=\mathrm{C} 1$ & 0.76 \\
PC & $\mathrm{O}=\mathrm{COC} 1 \mathrm{CCC}(\mathrm{CC} 1) \mathrm{C}(\mathrm{C})(\mathrm{C}) \mathrm{C} 2 \mathrm{CCC}(\mathrm{O}) \mathrm{CC} 2$ & 1.03 \\
PE & $\mathrm{CC}$ & 0.11 \\
PP & $\mathrm{CC}(\mathrm{C})$ & 0.13 \\
PVDF & $\mathrm{C}(\mathrm{F})(\mathrm{F}) \mathrm{C}$ & 0.15 \\
PTFE & $\mathrm{C}(\mathrm{F})(\mathrm{F}) \mathrm{C}(\mathrm{F})(\mathrm{F})$ & 0.15 \\
Parylene C & $\mathrm{CC} 1=\mathrm{CC}=\mathrm{C}(\mathrm{C}(=\mathrm{C} 1) \mathrm{Cl}) \mathrm{C}$ & 0.48 \\
PET & $\mathrm{O}=\mathrm{C}(\mathrm{O}) \mathrm{C} 1 \mathrm{CCC}(\mathrm{CC} 1) \mathrm{C}(=\mathrm{O}) \mathrm{OCC}$ & 0.80 \\
Cellulose & $\mathrm{OC} 1 \mathrm{C}(\mathrm{CO}) \mathrm{OC}(\mathrm{C}(\mathrm{C} 1 \mathrm{O}) \mathrm{O})$ & 1.00 \\
PA66 & $\mathrm{NCCCCCCNC}(=\mathrm{O}) \mathrm{CCCCC}=\mathrm{O}$ & 1.08 \\
\hline
\end{tabular}

\section{3) Physical processes:}

a) Relaxation: The importance of relaxation related aging is often underestimated. For example, it is our experience that the stability of Polymer Optical Fiber (POF) sensors based on inscribed Fiber Bragg Gratings (FBGs) is very dependent on whether the POF has been annealed or solvent exposure relaxed [47]-[51]. Also, we have observed severe crazing on un-relaxed POF surfaces when exposed to certain solvents. However, if the fibers are relaxed prior to exposure by annealing for a couple of days close to the $T_{g}$ of the polymer or by storage at room temperature for some months, we observe no crazing.

According to Mark et al. [52] typical low temperature polymer relaxation activation energies are $0.10 \mathrm{eV}-0.83 \mathrm{eV}$. Conformational changes in polymers which may be related to relaxation physical aging have activation energies around $0.1 \mathrm{eV}-0.23 \mathrm{eV}$ [53], [54].

b) Diffusion: Many chemical and physical degradation modes like for instance oxygenation and solvent plasticization are diffusion limited [1], [18], [55]-[57]. Note, that eq. (9) is also valid when replacing the rate constant $k$ with diffusivities $D$. For diffusion processes in polymers typical activation energies below $T_{g}$ are $0.26 \mathrm{eV}-0.52 \mathrm{eV}$. Above $T_{g}$ they can be be much higher [58]. 


\section{B. Range of temperatures for accelerated medical device polymer degradation tests}

Temperatures for accelerated polymer testing should not be so far from the application temperature range that degradation mechanisms change because this will result in uncertain predictions. Further, for predictions based on Arrhenius plots, temperature intervals which include no materials transitions like $T_{g}$ should be used. Degradation mechanism changes may lead to curvature in Arrhenius plots already around $60^{\circ} \mathrm{C}$ to $80^{\circ} \mathrm{C}$ like for the elastomers and PP studied by Celina et al. [18]. Above these temperatures $E_{A}$ 's are higher. Deviation from straight line Arrhenius plot behavior for PP starts already at $70^{\circ} \mathrm{C}$ [59]. Thus, it has been generally accepted that a good temperature interval for medical device polymer testing is approximately $25^{\circ} \mathrm{C}$ to $60{ }^{\circ} \mathrm{C}$ which is also used in standards [3], [6].

\section{Averages of $\rho$}

From the preceding sections it follows that most medical device thermally accelerated polymer aging studies are made in the region $\mathrm{Q}=\left[25^{\circ} \mathrm{C} \leq T_{1} \leq 70^{\circ} \mathrm{C}\right] \times\left[0.1 \mathrm{eV} \leq E_{a} \leq\right.$ $0.9 \mathrm{eV}]$. Assuming that the average of $\rho$ over this region represents average observations, it can be used as an indication of how well the $10^{\circ} \mathrm{C}$ rule can be used in general. For each $\Delta T$ the average is:

$$
\begin{aligned}
& \bar{\rho}_{Q, \Delta T}=\frac{\iint_{S} \rho_{\Delta T} d A}{\text { Area of } S} \\
& =\frac{\int_{0.1 \mathrm{eV}}^{0.9 \mathrm{eV}} \int_{25^{\circ} \mathrm{C}}^{70^{\circ} \mathrm{C}} \rho_{\Delta T} \sigma_{\Delta T} d T_{1} d E_{A}}{\int_{0.1 \mathrm{eV}}^{0.9 \mathrm{eV}} \int_{25^{\circ} \mathrm{C}}^{70{ }^{\circ} \mathrm{C}} \sigma_{\Delta T} d T_{1} d E_{A}}
\end{aligned}
$$

where $S$ is the surface in Fig. 1 defined by $\rho$ over $Q, T_{1}$ is the reference temperature in Kelvin and $\sigma_{\Delta T}$ is:

$$
\sigma_{\Delta T}=\sqrt{1+\left(\frac{\partial \rho}{\partial T_{1}}\right)_{\Delta T}^{2}+\left(\frac{\partial \rho}{\partial E_{A}}\right)_{\Delta T}^{2}}
$$

Another approach is to suggest that a reaction rate ratio estimate at a certain reference temperature $T_{1}$ and $\Delta T$ in case of unknown activation energy should be based on an average of eq. (9) over typical activation energies according to:

$$
\begin{aligned}
\bar{\rho}_{T_{1}, \Delta T}= & \frac{1}{0.8} \int_{0.1 \mathrm{eV}}^{0.9 \mathrm{eV}} \rho_{T_{1}, \Delta T} d E_{A} \\
= & 1.25 \mathrm{k}_{\mathrm{B}} \frac{T_{1}\left(T_{1}+\Delta T\right)}{\Delta T} \\
& \left(\mathrm{e}^{\frac{0.9 \mathrm{eV}}{\mathrm{k}_{\mathrm{B}}}} \frac{\Delta T}{T_{1}\left(T_{1}+\Delta T\right)}-\mathrm{e}^{\frac{0.1 \mathrm{eV}}{\mathrm{k}_{\mathrm{B}}}} \frac{\Delta T}{T_{1}\left(T_{1}+\Delta T\right)}\right)
\end{aligned}
$$

\section{ANAlysis}

All calculations in this analysis were made with Maple 2018. By looking at the $\rho$ surface in Fig. 1, both eqs. (12) and (14) seem as promising candidates to explain the $Q_{10}=2$ rule. Equation (14) finds extra support from Fig. 1 because $\rho \in[1,3]$ for $T_{1}=25^{\circ} \mathrm{C}$ and $\Delta T=10^{\circ} \mathrm{C}$ in good agreement with observations. Table II gives a quick overview of how well the rule corresponds with these averages for
$\Delta T=\left\{10^{\circ} \mathrm{C}, 20^{\circ} \mathrm{C}, 30^{\circ} \mathrm{C}, 40^{\circ} \mathrm{C}\right\}$. It is clearly seen that the rule is best explained by $\bar{\rho}_{25^{\circ} \mathrm{C}, \Delta T} \cdot \bar{\rho}_{Q, \Delta T}$ deviates from the rule with $4 \%$ to $27 \%$ whereas $\bar{\rho}_{25{ }^{\circ} \mathrm{C}, \Delta T}$ only deviates with $1 \%$ to $4 \%$.

TABLE II

EQUATIONS (12) AND (14) COMPARED WITH THE $10^{\circ} \mathrm{C}$ RULE

\begin{tabular}{cccc}
\hline \hline $\boldsymbol{\Delta} \boldsymbol{T}\left({ }^{\circ} \mathbf{C}\right)$ & $\boldsymbol{Q}_{\mathbf{1 0}}=\mathbf{2}^{\frac{\Delta \boldsymbol{T}}{{ }^{\circ} \mathbf{C}}}$ & $\bar{\rho}_{\boldsymbol{Q}, \boldsymbol{T}}$ & $\overline{\boldsymbol{\rho}}_{\mathbf{2 5}{ }^{\circ} \mathbf{C}, \boldsymbol{\Delta} \boldsymbol{T}}$ \\
\hline 10 & 2 & 1.90 & 1.96 \\
20 & 4 & 4.15 & 3.97 \\
30 & 8 & 9.53 & 8.14 \\
40 & 16 & 21.93 & 16.68 \\
\hline
\end{tabular}

The correlation coefficient between rule and $\bar{\rho}_{25{ }^{\circ} \mathrm{C}, \Delta T}$ data for $\Delta T=\left\{10^{\circ} \mathrm{C}, 20^{\circ} \mathrm{C},,, 80^{\circ} \mathrm{C}\right\}$ is $r=0.9996$. Best fit of the base in $a^{\frac{\Delta T}{10^{\circ} \mathrm{C}}}$ to the $\bar{\rho}_{25{ }^{\circ} \mathrm{C}, \Delta T}$ data for the same $\Delta T$ 's returns $a=1.9991$. From this, it is clear that the $10^{\circ} \mathrm{C}$ rule is good for $E_{A} \in[0.1 \mathrm{eV}, 0.9 \mathrm{eV}], T_{1}=25^{\circ} \mathrm{C}$ and $\Delta T \in\left[10^{\circ} \mathrm{C}, 80^{\circ} \mathrm{C}\right]$. This result is strongly dependent on the $E_{a}$ interval $\rho$ is averaged over and therefore the rule's empirical success supports the suggestion that typically $E_{A} \in[0.1 \mathrm{eV}, 0.9 \mathrm{eV}]$. This is also the case at other $T_{1}$ 's as activation energies are only weakly temperature dependent [28]. From the survey of available $E_{A}$ data it also seems that the interval is especially well documented for polymers. Also, the suggested interval of most common activation energies $E_{A} \in[0.1 \mathrm{eV}, 0.9 \mathrm{eV}]$ is consistent with the best fit of $\bar{\rho}_{25^{\circ} \mathrm{C}, \Delta T}=\frac{1}{|y|-|x|} \int_{|x|}^{|y|} \rho_{25}{ }^{\circ} \mathrm{C}, \Delta T d E_{A}$ to the $10^{\circ} \mathrm{C}$ rule which gives $E_{A} \in[0.0000 \mathrm{eV}, 0.9223 \mathrm{eV}]$ for $\Delta T=\left\{10^{\circ} \mathrm{C}, 20^{\circ} \mathrm{C},, 80^{\circ} \mathrm{C}\right\}$. If it is decided to put $x=0.1 \mathrm{eV}$, the best fit for $y$ gives $y=0.9013 \mathrm{eV}$. Best fits at higher $T_{1}$ 's naturally result in wider $E_{A}$ intervals. Fig. 2 shows $\bar{\rho}_{T_{1}, \Delta T}$ for $T_{1} \in\left[25^{\circ} \mathrm{C}, 70^{\circ} \mathrm{C}\right]$ and $\Delta T \in\left[10^{\circ} \mathrm{C}, 40^{\circ} \mathrm{C}\right]$. To the left, the surface cut at $T_{1}=25{ }^{\circ} \mathrm{C}$ shows the course of $\bar{\rho}_{25^{\circ} \mathrm{C}, \Delta T}$. The graph clearly shows that the rule is valid at $25^{\circ} \mathrm{C}$ only. At other higher $T_{1}$ 's other similar rules apply where the base $a$ is smaller. Thus, at $37^{\circ} \mathrm{C}$ we for instance have $\bar{\rho}_{37^{\circ} \mathrm{C}}^{\text {Rule }}(\Delta T) \approx 1.8955^{\frac{\Delta T}{10^{\circ} \mathrm{C}}}$. In Fig. 3 all the mentioned rate ratios are compared. In Fig. 4 it can be seen, that in the interval $\Delta T \in\left[10^{\circ} \mathrm{C}, 80^{\circ} \mathrm{C}\right]$ the maximum deviation of $\bar{\rho}_{25^{\circ} \mathrm{C}, \Delta T}$ from the rule is approximately $5.5 \%$ for $\Delta T \approx 53{ }^{\circ} \mathrm{C}$.

The importance of only applying the $10^{\circ} \mathrm{C}$ rule with caution is illustrated with an example from the literature: Hukins et al. [2] calculated the aging rate acceleration factor for a general on-body or implanted medical device which in use experiences $T_{1}=37^{\circ} \mathrm{C}$, using the $10{ }^{\circ} \mathrm{C}$ rule, eq. (2), for $T_{2}=87{ }^{\circ} \mathrm{C}$, or $\Delta T=87^{\circ} \mathrm{C}-37^{\circ} \mathrm{C}=50^{\circ} \mathrm{C}: Q_{10}\left(\Delta T=50^{\circ} \mathrm{C}\right)=2^{\frac{50^{\circ} \mathrm{C}}{10^{\circ} \mathrm{C}}}=$ $2^{5}=32$. According to our analysis a more correct value is $\bar{\rho}_{37^{\circ} \mathrm{C}}^{\text {Rule }}\left(\Delta T=50^{\circ} \mathrm{C}\right)=1.8955^{5}=24.5$. By using eq. (14) directly we get the even more precise value $\bar{\rho}_{37{ }^{\circ} \mathrm{C}, 50{ }^{\circ} \mathrm{C}}=25.4$. The difference to $Q_{10}\left(\Delta T=50{ }^{\circ} \mathrm{C}\right)$ is $20.6 \%$ ! Obviously, that large differences in acceleration factor estimates may have great safety and/or economic consequences.

The activation energy $E_{a}=0.55 \mathrm{eV}$ is often mentioned as the activation energy for a reaction which doubles its 


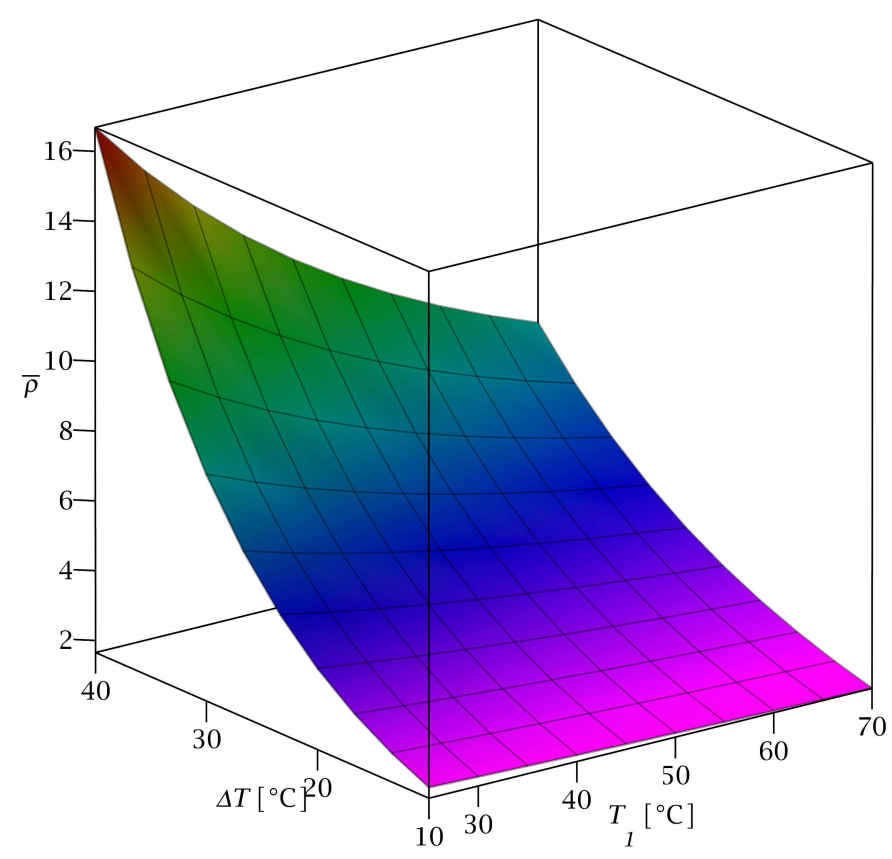

Fig. 2. The temperature dependence of $\bar{\rho}_{T_{1}, \Delta T}$ according to eq. (14).

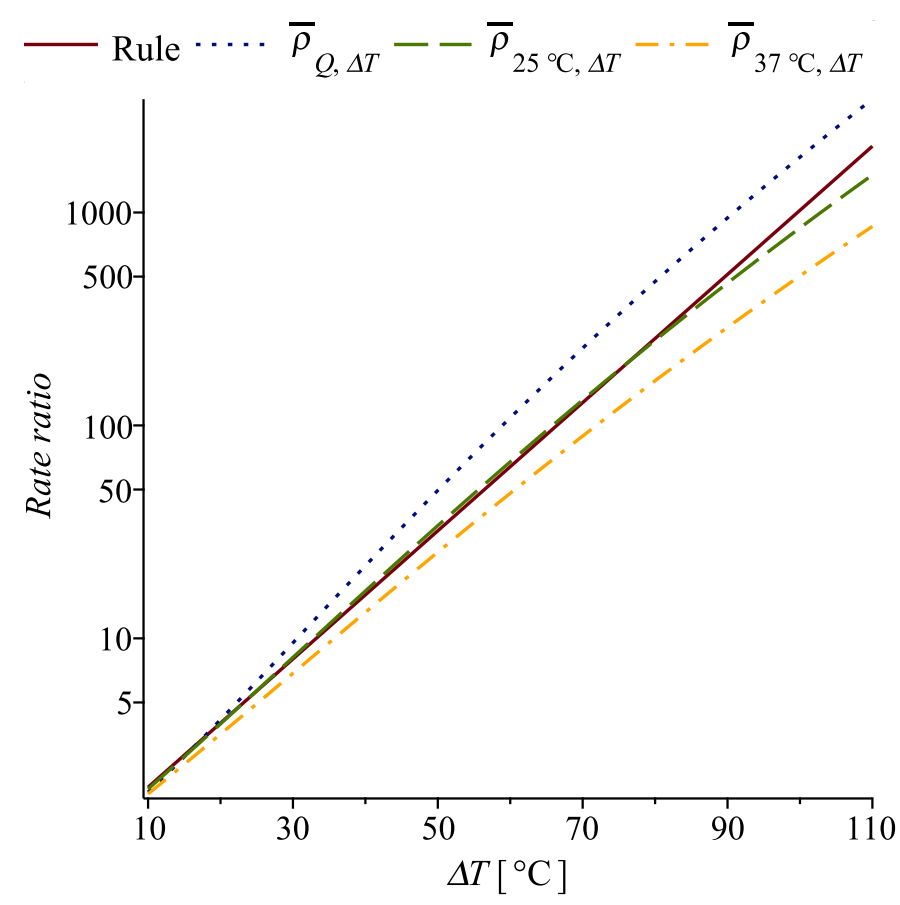

Fig. 3. Rate ratios as a function of $\Delta T$ compared.

rate when the temperature is increased by $10{ }^{\circ} \mathrm{C}$ [60]. This value is found by just equating the $10^{\circ} \mathrm{C}$ rule eq. (1) with eq. (9) at $T_{1}=25^{\circ} \mathrm{C}, \Delta T=10^{\circ} \mathrm{C}$ c.f. eq. (10) and not using that for $\Delta T=20^{\circ} \mathrm{C}$ the reaction rate is four times higher and so on. To obtain a better activation energy estimate for a reaction which follows the $10^{\circ} \mathrm{C}$ rule, the Arrhenius expression eq. (9) can be fitted to rule data. Lambert et al. [5] have attempted this for $Q_{10}=2$ aging with $T_{1}=25^{\circ} \mathrm{C}$ and $\Delta T=\left\{10^{\circ} \mathrm{C}, 20^{\circ} \mathrm{C}, 30^{\circ} \mathrm{C}, 40^{\circ} \mathrm{C}\right\}$ up to a maximum temperature of $65^{\circ} \mathrm{C}$. Here, the activation energy found was $0.59 \mathrm{eV}$. The argument for limiting the range to $65^{\circ} \mathrm{C}$ is not that this

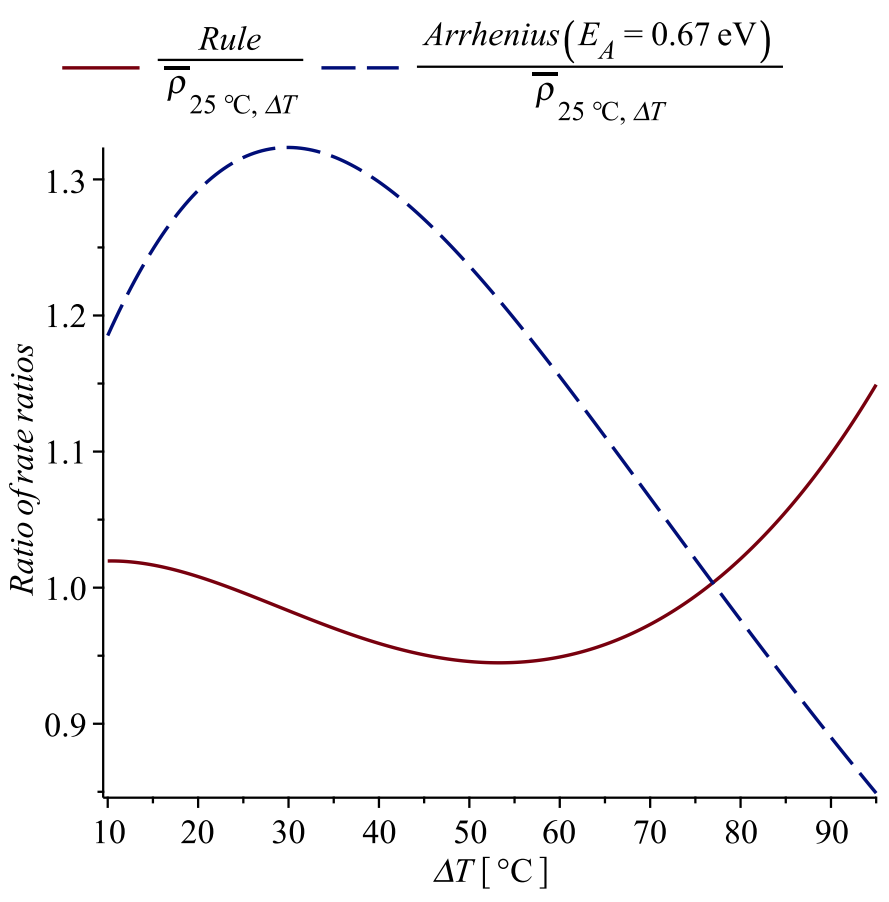

Fig. 4. Ratio of rate ratios as a function of $\Delta T$ at $T_{1}=25^{\circ} \mathrm{C}$.

gives a good general $E_{A}$ estimate to use if the real value is unknown, but that this is the maximum used in medical device testing [6]. However, the application in a narrow interval should not influence the temperature interval to find the best fit apparent $E_{A}$. Note namely, that the $E_{A}$ calculated by such fitting is strongly dependent on the used $\Delta T$ range, which is also found by Lambert et al. [5], where a fit up to $135^{\circ} \mathrm{C}$ is also made, giving $E_{A}=0.73 \mathrm{eV}$. However, it is not commented that for the same reaction mechanism, $E_{A}$ does almost not vary with temperature. The variation with temperature is actually experimentally undetectable [28]. Hence, there is a need for a single more broadly applicable $E_{A}$ estimate, i.e. one that holds reasonably well for a wider $\Delta T$ range starting from $25^{\circ} \mathrm{C}$ and which can therefore be used as a best guess if the real value is unknown. Our finding, that according to the Arrhenius reaction rate ratio, the $10^{\circ} \mathrm{C}$ rule is most valid for $T_{1}=25^{\circ} \mathrm{C}$ and $\Delta T=\left\{10^{\circ} \mathrm{C}, 20^{\circ} \mathrm{C},,, 80^{\circ} \mathrm{C}\right\}$, Figs. $2-4$, suggests that a good rule of thumb $E_{A}$ value can be found using these inputs for fitting, see the result in Fig. 5. From the fit we get $E_{A}^{\text {Rule }}=0.67 \mathrm{eV}$. The correlation coefficient for the two sets of data for $\Delta T=\left\{10^{\circ} \mathrm{C}, 20^{\circ} \mathrm{C},,, 80^{\circ} \mathrm{C}\right\}$ is 0.9963 . The correlation coefficient can of cause get closer to 1 using a more narrow low end $\Delta T$ interval for the fit, but as indicated earlier, that will be at the expense of very bad agreement with the rule at higher temperatures. The ratio of rule and Arrhenius rate ratios using $E_{A}=0.55 \mathrm{eV}, T_{1}=25^{\circ} \mathrm{C}$ increases with $\Delta T$ and is larger than 1 for all $\Delta T>10^{\circ} \mathrm{C}$ and the difference between the two ratios is already around $50 \%$ at $\Delta T=50^{\circ} \mathrm{C}$. Using $E_{A}^{\text {Rule }}=0.67 \mathrm{eV}$, the maximum deviation between $\bar{\rho}_{25^{\circ} \mathrm{C}, \Delta T}$ and Arrhenius rate ratios is approximately $32.5 \%$ for $T_{1}=25^{\circ} \mathrm{C}$ and $\Delta T \in\left[10^{\circ} \mathrm{C}, 80^{\circ} \mathrm{C}\right]$, see Fig. 4. Fig. 5 shows that at higher $\Delta T$ 's than approximately $90^{\circ} \mathrm{C}$, the rule can be regarded as not in agreement with the Arrhenius rate 


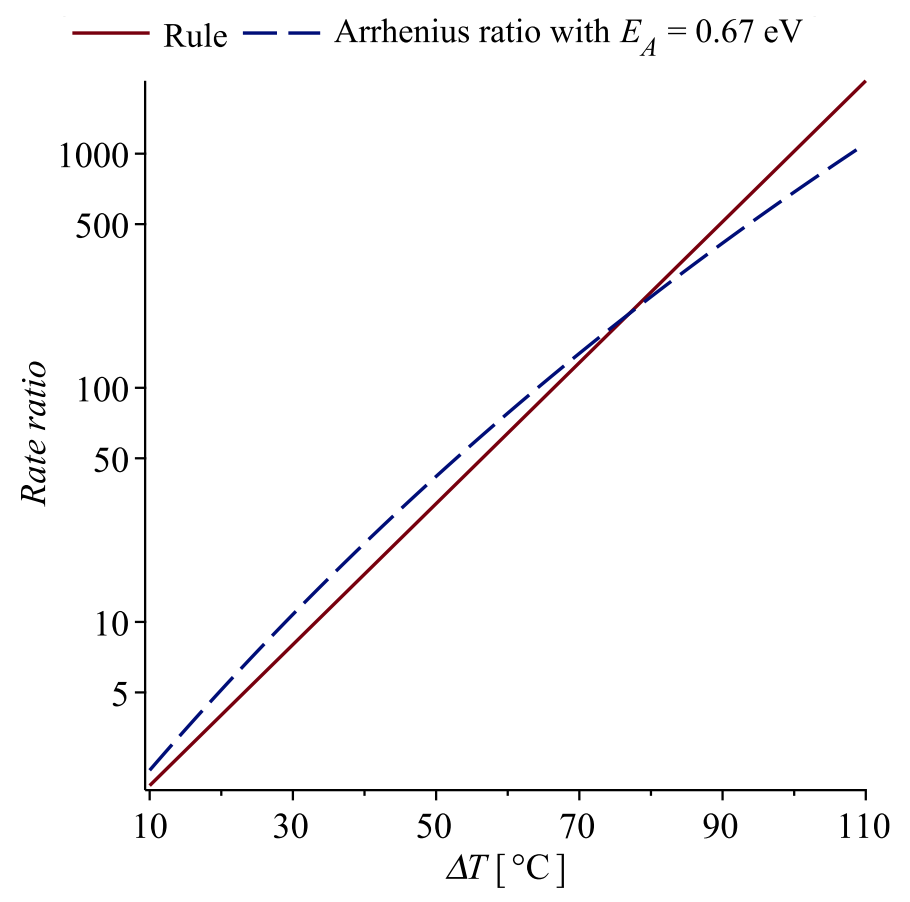

Fig. 5. Comparison of rule ratios with Arrhenius rate ratios using $T_{1}=25^{\circ} \mathrm{C}$ and $E_{A}=0.67 \mathrm{eV}$ obtained by Arrhenius rate ratio fit to the rule ratios.

ratio equation eq. (9) using $T_{1}=25^{\circ} \mathrm{C}, E_{A}=0.67 \mathrm{eV}$. Regarding medical device testing, it is worth noting that also for $T_{1}=37^{\circ} \mathrm{C}$ the maximum deviation from $\bar{\rho}_{37^{\circ} \mathrm{C}, \Delta T}$ is around $32.5 \%$ for $\Delta T \in\left[10^{\circ} \mathrm{C}, 80^{\circ} \mathrm{C}\right]$, see Fig. 6 . The validity of $E_{A}^{\text {Rule }}=0.67 \mathrm{eV}$ is well supported by several papers and standards [42]-[44], where average observed activation energies are $0.65 \mathrm{eV}-0.70 \mathrm{eV}$. However, when comparing the Arrhenius rate ratio at $T_{1}=25^{\circ} \mathrm{C}$ and $T_{1}=37^{\circ} \mathrm{C}$ using $E_{A}^{\text {Rule }}=0.67 \mathrm{eV}$ and the $10^{\circ} \mathrm{C}$ rule with the generally more accurate estimates $\bar{\rho}_{25^{\circ} \mathrm{C}, \Delta T}, \bar{\rho}_{37^{\circ} \mathrm{C}, \Delta T}$, it is clear that for $\Delta T<50{ }^{\circ} \mathrm{C}$ the $10^{\circ} \mathrm{C}$ rule is superior, see Figs. 4,6 .

\section{CONCLUSIONS}

First, we note that although frequently claimed, the $10^{\circ} \mathrm{C}$ rule eq. (1) cannot be derived from the Arrhenius rate ratio equation (9). Further, under the (not always valid) assumption that an aging process exhibits Arrhenius behavior, we conclude that:

- The $10^{\circ} \mathrm{C}$ rule is quite accurate for $T_{1}=25^{\circ} \mathrm{C}, \Delta T \in$ $\left[10^{\circ} \mathrm{C}, 80^{\circ} \mathrm{C}\right]$ and $E_{A} \in[0.1 \mathrm{eV}, 0.9 \mathrm{eV}]$. At other reference temperatures $T_{1}$ the $10^{\circ} \mathrm{C}$ rule deviates significantly from Arrhenius behavior. However, for $T_{1} \neq 25^{\circ} \mathrm{C}$ more accurate similar rules $\bar{\rho}_{T_{1}}^{\text {Rule }}(\Delta T)=a_{T_{1}}^{\frac{\Delta T}{10^{\circ} \mathrm{C}}}$ where $a_{T_{1}} \neq 2$ can be found.

- Typical polymer thermal aging activation energies are $E_{A} \in[0.1 \mathrm{eV}, 0.9 \mathrm{eV}]$ for $T_{1} \in\left[25^{\circ} \mathrm{C}, 70^{\circ} \mathrm{C}\right]$.

- $\bar{\rho}_{T_{1}, \Delta T}$ which is theoretically better founded and includes reference temperature $T_{1}$ dependence is a more accurate rule than the $10^{\circ} \mathrm{C}$ rule and also than $\bar{\rho}_{T_{1}}^{\text {Rule }}(\Delta T)=$ $a_{T_{1} \mathrm{C}}^{\frac{\Delta T}{10^{\circ} \mathrm{C}}}$. It is therefore recommended to use this equation as a guideline in thermal acceleration of medical device

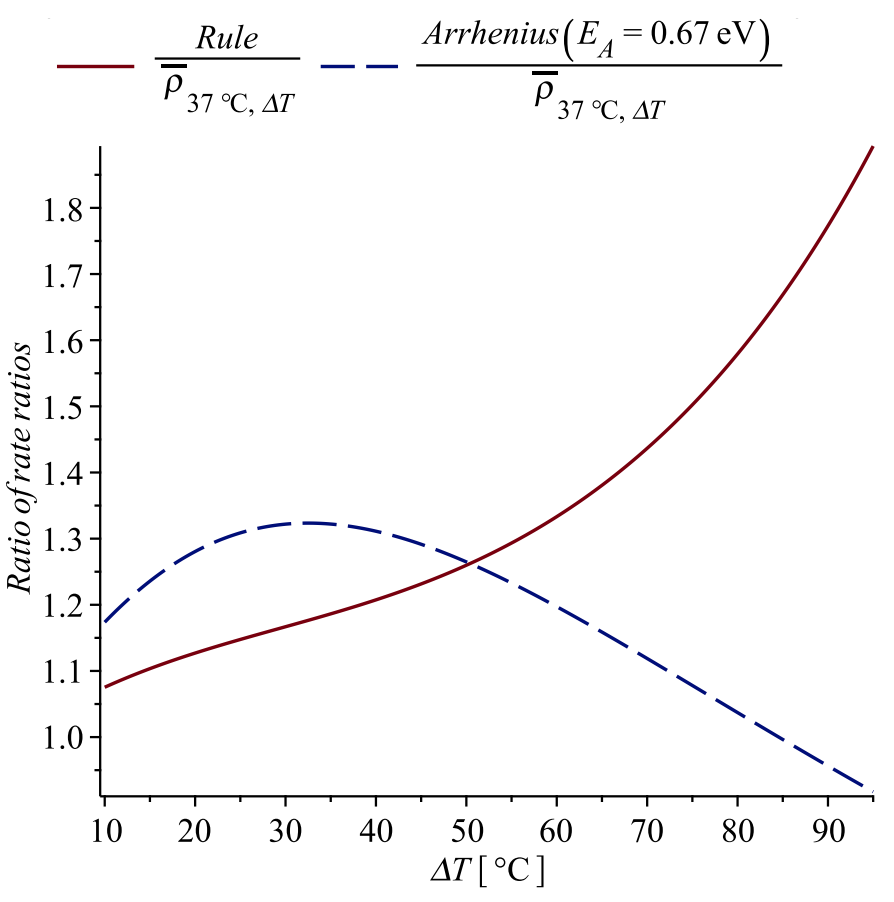

Fig. 6. Ratio of rate ratios as a function of $\Delta T$ at $T_{1}=37^{\circ} \mathrm{C}$.

polymer aging instead of the $10^{\circ} \mathrm{C}$ rule, especially when using other reference temperatures than $T_{1}=25^{\circ} \mathrm{C}$.

- Best agreement between the $10^{\circ} \mathrm{C}$ rule and the reaction rate ratio eq. (9) based on the Arrhenius equation using the reference temperature $25^{\circ} \mathrm{C}$, is achieved with an aging activation energy $E_{A}^{\text {Rule }}=0.67 \mathrm{eV}$.

By this, we hope to have contributed to a better understanding of the background and limitations of the widely used $10{ }^{\circ} \mathrm{C}$ rule.

\section{ACKNOWLEDGMENT}

This work was supported by: The European Maritime and Fisheries Fund, The Danish Fisheries Agency and The People Programme (Marie Curie Actions) of the European Union's Seventh Framework Programme FP7/2007-2013/ under REA Grant Agreement n 608382.

\section{REFERENCES}

[1] J. Janting, Microsystem reliability: Polymer adhesive and coating materials for packaging. Lambert Academic Publishing, 2010.

[2] D. W. L. Hukins, A. Mahomed, and S. N. Kukureka, "Accelerated aging for testing polymeric biomaterials and medical devices," Medical Engineering and Physics, vol. 30, no. 10, pp. 1270-1274, 2008. [Online]. Available: http://dx.doi.org/10.1016/j.medengphy.2008.06.001

[3] American Society for Testing and Materials (ASTM), ASTM F1980 - 07 Standard Guide for Accelerated Aging of Sterile Barrier Systems for Medical Devices, 2012. [Online]. Available: https://doi.org/10.1520/F1980-07R11

[4] K. J. Hemmerich, "General Aging Theory and Simplified Protocol for Accelerated Aging of Medical Devices," Medical Plastics and Biomaterials, pp. 16-23, 1998.

[5] B. J. Lambert and F. W. Tang, "Rationale for practical medical device accelerated aging programs in AAMI TIR 17," Radiation Physics and Chemistry, vol. 57, no. 3-6, pp. 349-353, 2000. [Online]. Available: https://doi.org/10.1016/S0969-806X(99)00403-X

[6] Technical Information Report. AAMI TIR17:2008. Compatibility of materials subject to sterilization, Association for the Advancement of Medical Instrumentation (AAMI), 2008. 
[7] E. B. Welch and T. Lindell, Ecological Effects of Waste Water: Applied limnology and pollutant effects, 2nd ed. Cambridge University Press, 1992, ch. 6, p. 121.

[8] R. Myers, "Kinetics and Equilibrium," in The Basics of Chemistry, R. E. Krebs, Ed. GREENWOOD PRESS, 2003, ch. 12, p. 142.

[9] J. H. V. Hoff, Studies in chemical dynamics. Amsterdam: Kessinger Publishing, LLC, 1896, ch. Temperature influence on chemical reactions, pp. $122-125$.

[10] K. J. Laidler, "The development of the Arrhenius equation," Journal of Chemical Education, vol. 61, pp. 494-498, 1984. [Online]. Available: http://dx.doi.org/10.1021/ed061p494

[11] — Reaction kinetics, 1st ed. Oxford: Pergamon Press, 1963, vol. 1: Homogeneous Gas Reactions, ch. 2, pp. 45-46.

[12] A. Holleman, Inorganic Chemistry, 1st ed. San Diego: Academic Press, 2001, ch. VII, pp. 185, 169.

[13] J. H. Van't Hoff, Etudes de dynamique chimique. Amsterdam: F. Mullet and Co., 1884.

[14] C. P. Cohen Stuart, "A study of temperature-coefficients and van 't Hoff's rule," in KNAW, Proceedings, 14 II, 1911-1912. Amsterdam: Huygens Institute - Royal Netherlands Academy of Arts and Sciences (KNAW), 1912, pp. 1159-1173.

[15] A. R. Cossins, Temperature biology of animals. Springer Netherlands, 1987, ch. The direct effects of temperature changes, pp. 29-30.

[16] S. Arrhenius, "Über die reaktionsgeschwindigkeit bei der inversion von rohrzucker durch säuren," Zeit. phys. Chem., no. 4, pp. 226-248, 1889.

[17] D. L. Allara, "Aging of polymers," Environmental Health Perspectives, vol. vol.11, no. June, pp. 29-33, 1975. [Online]. Available: http://dx.doi.org/10.1289/ehp.751129

[18] M. C. Celina, "Review of polymer oxidation and its relationship with materials performance and lifetime prediction," Polymer Degradation and Stability, vol. 98, no. 12, pp. 2419-2429, 2013. [Online]. Available: http://dx.doi.org/10.1016/j.polymdegradstab.2013.06.024

[19] S. Lyu and D. Untereker, "Degradability of polymers for implantable biomedical devices," International Journal of Molecular Sciences, vol. 10, no. 9, pp. 4033-4065, 2009. [Online]. Available: https://dx.doi.org/10.3390/ijms10094033

[20] J. R. White, "Polymer ageing: physics, chemistry or engineering? time to reflect," Comptes Rendus Chimie, vol. 9, no. 11-12, pp. 1396-1408, 2006. [Online]. Available: http://dx.doi.org/10.1016/j.crci.2006.07.008

[21] A. S. Maxwell, W. R. Broughton, G. Dean, and G. D. Sims, "Review of accelerated ageing methods and lifetime prediction techniques for polymeric materials," National Physical Laboratory (NPL), Hampton Road, Teddington, Middlesex, TW11 0LW, Tech. Rep., 2005.

[22] S. Glasstone, K. J. Laidler, and H. Eyring, The theory of rate processes, the kinetics of chemical reactions, viscosity, diffusion and electrochemical phenomena. New York and London: McGraw-Hill Book Company, Inc., 1941, ch. IV, p. 152

[23] P. Atkins and J. de Paula, Physical chemistry. New York: Oxford University Press, 2006, ch. Data section, p. 1011.

[24] W. M. Haynes, Ed., Handbook of Chemistry and Physics, 97th ed., ser. Internet Version 2017. CRC Press/Taylor \& Francis, Boca Raton, FL., 2017, ch. Bond dissociation energies.

[25] J. A. Manion, R. E. Huie, R. D. Levin, D. R. Burgess Jr., V. L. Orkin, W. Tsang, W. S. McGivern, J. W. Hudgens, V. D. Knyazev, D. B Atkinson, E. Chai, A. M. Tereza, C.-Y. Lin, T. C. Allison, W. G. Mallard, F. Westley, J. T. Herron, R. F. Hampson, and D. H. Frizzell, "Nist chemical kinetics database, nist standard reference database 17, version 7.0 (web version), release 1.6.8, data version 2016.10, national institute of standards and technology, gaithersburg, maryland, 208998320," http://kinetics.nist.gov/kinetics/index.jsp.

[26] R. C. Tolman, "Statistical merchanics applied to chemical kinetics," $J$. Amer. Chem. Soc., vol. 42, no. 12, pp. 2506-2528, 1920. [Online]. Available: https://doi.org/10.1021/ja01457a008

[27] D. G. Truhlar, B. C. Garrett, and S. J. Klippenstein, "Current Status of Transition-State Theory," J. Phys. Chem., vol. 100, no. 31, pp. 1277112 800, 1996. [Online]. Available: https://doi.org/10.1021/jp953748q

[28] R. W. Carr, Modeling of Chemical Reactions, 1st ed. Elsevier, 2007, vol. 42, ch. 3: Elements of Chemical Kinetics, p. 52.

[29] H. Johnston and J. Birks, "Activation energies for the dissociation of diatomic molecules are less than the bond dissociation energies," Accounts of Chemical Research, vol. 5, no. 10, pp. 327-335, 1972. [Online]. Available: https://doi.org/10.1021/ar50058a002

[30] P. H. Mott and C. M. Roland, "Aging of Natural Rubber in Air and Seawater," Rubber Chemistry and Technology, vol. 74, no. 1, pp. 79-88, 2001. [Online]. Available: http://dx.doi.org/10.5254/1.3547641
[31] M. Celina and K. Gillen, Service Life Prediction of Polymeric Materials. Global Perspectives. New York: Springer, 2009, ch. 3: Advances in Exploring Mechanistic Variations in Thermal Aging of Polymers, p. 48. [32] E. S. Gonçalves, L. Poulsen, and P. R. Ogilby, "Mechanism of the temperature-dependent degradation of polyamide 66 films exposed to water," Polymer Degradation and Stability, vol. 92, no. 11, pp. 1977-1985, 2007. [Online]. Available: http://dx.doi.org/10.1016/j.polymdegradstab.2007.08.007

[33] S. Kahlen, G. M. Wallner, and R. W. Lang, "Aging behavior and lifetime modeling for polycarbonate," Solar Energy, vol. 84, no. 5, pp. 755-762, 2010. [Online]. Available: http://dx.doi.org/10.1016/j.solener.2010.01.021

[34] J. E. Pickett and J. R. Sargent, "Sample temperatures during outdoor and laboratory weathering exposures," Polymer Degradation and Stability, vol. 94, no. 2, pp. 189-195, 2009. [Online]. Available: http://dx.doi.org/10.1016/j.polymdegradstab.2008.11.005

[35] F. W. Billmeyer, Textbook of polymer science. Interscience Publisher, a Division of John Wiley and Sons, 1962, ch. 9, pp. 287-288.

[36] J. M. G. Cowie, Polymers: Chemistry \& physics of modern materials. International Textbook Company Limited, 1973, ch. 3, 4, pp. 64, 77.

[37] P. Lall, "Tutorial: Temperature as an input to microelectronics-reliability models," IEEE Transactions on Reliability, vol. 45, no. 1, pp. 3-9, 1996. [Online]. Available: http://dx.doi.org/10.1109/24.488908

[38] J. W. McPherson, Reliability physics and engineering, 2nd ed. Springer, 2013, ch. Appendix C, p. 379.

[39] Ö. Hallberg and D. S. Peck, "Recent humidity accelerations, a base for testing standards," Quality and Reliability Engineering International, vol. 7, no. 3, pp. 169-180, 1991. [Online]. Available: http://dx.doi.org/10.1002/qre.4680070308

[40] P. Lall, M. Pecht, and E. B. Hakim, "Characterization of functional relationship between temperature and microelectronic reliability," Microelectronics Reliability, vol. 35, no. 3, pp. 377-402, 1995. [Online]. Available: http://dx.doi.org/10.1016/0026-2714(95)93067-K

[41] O. Haillant, D. Dumbleton, and A. Zielnik, "An Arrhenius approach to estimating organic photovoltaic module weathering acceleration factors," Solar Energy Materials and Solar Cells, vol. 95, no. 7, pp. 1889-1895, 2011. [Online]. Available: http://dx.doi.org/10.1016/j.solmat.2011.02.013

[42] F. Bayle and A. Mettas, "Temperature acceleration models in reliability predictions: Justification \& improvements," Proceedings - Annual Reliability and Maintainability Symposium, 2010. [Online]. Available: http://dx.doi.org/10.1109/RAMS.2010.5448028

[43] A. I. Dell, S. Pawar, and V. M. Savage, "Systematic variation in the temperature dependence of physiological and ecological traits," Proceedings of the National Academy of Sciences of the United States of America, vol. 108, no. 26, pp. 10591-10596, 2011. [Online]. Available: http://dx.doi.org/10.1073/pnas.1015178108

[44] EFSA, "Opinion on a request from EFSA related to the default Q 10 value used to describe the temperature effect on transformation rates of pesticides in soil," EFSA Journal, vol. 622, pp. 1-32, 2007.

[45] T. J. Wolery, Encyclopedia of geochemistry. Dordrecht: Kluwer Academic Publishers, 1999, ch. Activation Energy, Activation Enthalpy, Activation Volume.

[46] C. M. Hansen, Hansen Solubility Parameters. CRC Press, 2007, ch. 1, pp. $6,18$.

[47] J. Janting, J. Pedersen, R. Inglev, G. Woyessa, K. Nielsen, and O. Bang, "Effects of solvent etching on pmma microstructured optical fiber bragg grating," Journal of Lightwave Technology, pp. 1-1, 2019. [Online]. Available: http://dx.doi.org/10.1109/JLT.2019.2902244

[48] A. Fasano, G. Woyessa, J. Janting, H. K. Rasmussen, and O. Bang, "Solution-mediated annealing of polymer optical fiber bragg gratings at room temperature," I E E E Photonics Technology Letters, vol. 29, no. 8, pp. 687-690, 2017. [Online]. Available: http://dx.doi.org/10.1109/LPT.2017.2678481

[49] G. Woyessa, A. Fasano, A. Stefani, C. Markos, K. Nielsen, H. K. Rasmussen, and O. Bang, "Single mode step-index polymer optical fiber for humidity insensitive high temperature fiber Bragg grating sensors," Optics Express, vol. 24, no. 2, p. 1253, 2016. [Online]. Available: https://dx.doi.org/10.1364/OE.24.001253

[50] G. Woyessa, K. Nielsen, A. Stefani, C. Markos, and O. Bang, "Temperature insensitive hysteresis free highly sensitive polymer optical fiber Bragg grating humidity sensor." Optics express, vol. 24, no. 2, pp. 1206-13, 2016. [Online]. Available: https://dx.doi.org/10.1364/OE.24.001206

[51] A. Fasano, G. Woyessa, P. Stajanca, C. Markos, A. Stefani, K. Nielsen, H. K. Rasmussen, K. Krebber, and O. Bang, "Fabrication and characterization of polycarbonate microstructured polymer optical 
fibers for high-temperature-resistant fiber Bragg grating strain sensors," Optical Materials Express, vol. 6, no. 2, p. 649, 2016. [Online]. Available: https://dx.doi.org/10.1364/OME.6.000649

[52] J. E. Mark, Physical Properties of Polymers Handbook, 2nd ed. Springer, 2007, ch. 13, p. 218.

[53] I. Bahar and B. Erman, "Activation Energies of Local Conformational Transitions in Polymer Chains," Macromolecules, vol. 20, no. 9, pp. 2310-2311, 1987. [Online]. Available: https://dx.doi.org/10.1021/ma00175a043

[54] R. Wu, B. Kong, and X. Yang, "Conformational transition characterization of glass transition behavior of polymers," Polymer, vol. 50, no. 14, pp. 3396-3402, 2009. [Online]. Available: http://dx.doi.org/10.1016/j.polymer.2009.05.013

[55] J. Wise, K. Gillen, and R. Clough, "Quantitative model for the time development of diffusion-limited oxidation profiles," Polymer, vol. 38, no. 8, pp. 1929-1944, 1997. [Online]. Available: https://dx.doi.org/10.1016/S0032-3861(96)00716-1

[56] A. Boubakri, N. Haddar, K. Elleuch, and Y. Bienvenu, "Impact of aging conditions on mechanical properties of thermoplastic polyurethane," Materials \& Design, vol. 31, no. 9, pp. 4194-4201, 2010. [Online]. Available: http://dx.doi.org/10.1016/j.matdes.2010.04.023

[57] P. Le Gac, D. Choqueuse, D. Melot, B. Melve, and L. Meniconi, "Life time prediction of polymer used as thermal insulation in offshore oil production conditions: Ageing on real structure and reliability of prediction," Polymer Testing, vol. 34, pp. 168-174, 2014. [Online]. Available: http://dx.doi.org/10.1016/j.polymertesting.2014.01.011

[58] C. E. Rogers, Polymer permeability. Chapman \& Hall, 1985, ch. 2 : Permeation of gasses and vapours in polymers, p. 64

[59] P. Richter, "Initiation Process in the Oxidation of Polypropylene," Macomolecules, vol. 3, no. 2, pp. 262-264, 1970. [Online]. Available: https://dx.doi.org/10.1021/ma60014a027

[60] M. Wallenstein, S. D. Allison, J. Ernakovich, J. Megan Steinweg, and R. Sinsabaugh, "Controls on the Temperature Sensitivity of Soil Enzymes: A Key Driver of In Situ Enzyme Activity Rates," in Soil enzymology, G. Shukla and A. Varma, Eds. Berlin Heidelberg: Springer-Verlag, 2011, vol. 22 , ch. 13 , p. 248. [Online]. Available: http://dx.doi.org/10.1007/978-3-642-14225-3_13

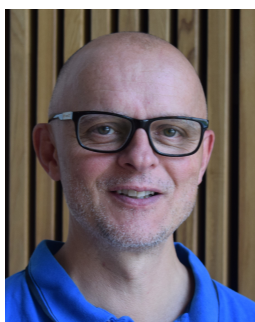

Jakob Janting J. Janting received his MSc degree in Materials Science from the University of Aarhus, Denmark in 1991. Here he was employed as a researcher affiliated to the Tribology Department from 1991 to 1994 in an EU project where he was working on micro focus X-ray strain measurements. In 1994, he joined the Department for Sensors at Grundfos Research where he worked in a national project on materials for advanced MEMS sensor packaging. From 1998 to 2011 he was employed at DELTA, Danish Electronics, Light \& Acoustics, where focus of his work was on polymer microsystem encapsulation. In 2008 he was awarded the $\mathrm{PhD}$ degree for a thesis on reliability of polymer adhesive and coating materials for microsystem packaging. From 2011 to 2015 he was employed at Medtronic where he worked on reliable packaging of an on-body combined electrochemical and fiber optical microsensor device for continuous blood glucose monitoring and insulin delivery. He got a postdoc position 2015 and a researcher position 2017 in the Fiber Sensors and Supercontinuum group, The Department of Photonics Engineering, Technical University of Denmark where focus of his research is on microstructured Polymer Optical Fiber (mPOF) bio/chemical sensors.

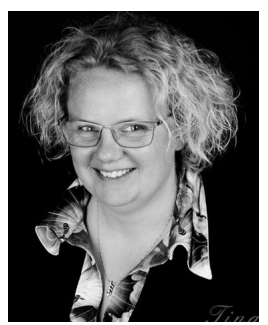

Julie G. Theander Julie Grundtvig Theander received the B.S. degree in Integrated Design from the University of Southern Denmark in 2006 and an EBA from the Engineering College of Copenhagen in 2016. She is currently occupied as a R\&D Project Manager with Convatec, Infusion Division taking new infusion sets from idea to registration and global launch with key areas being Design Control and Usability Engineering. Her previous occupations have all been within Medical-technology in both Medtronic (2012-2015) Unomedical (2006-2008), AMBU (2008-2009) and

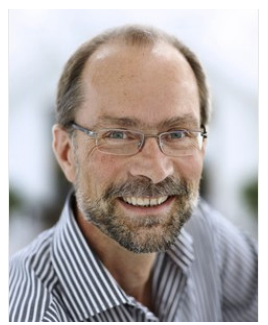

Henrik Egesborg Henrik Egesborg is a biomedical engineering professional with more than 30 years of experience from international pharmaceutical and medical device industry. Henrik Egesborg received an MSc degree in electronic engineering 1979 and a PhD in Physics 1984 from the Technical University of Denmark. He held specialist and managerial positions in several international companies and academia. E.g. he served as a Corporate Vice President for ten years in Novo Nordisk, a leading diabetes focused pharmaceutical company based in Denmark, organized and managed an R\&D organization in Copenhagen during six years for Medtronic, a leading US based medical device manufacturer. At the Technical University of Denmark he taught biomedical product development to graduate students for seven years. Currently he is responsible for medical device development in Ascendis Pharma, a Danish biotech company focusing on rare diseases in endocrinology. 